\title{
Transatlantica
}

Revue d'études américaines. American Studies Journal

$1 \mid 2012$

Le roman policier, littérature transatlantique / Maisons

Hantées

\section{The New American Wing at The Metropolitan Museum of Art, New York}

Jennifer A. Donnelly

\section{OpenEdition}

\section{Journals}

Édition électronique

URL : https://journals.openedition.org/transatlantica/5835

DOI : $10.4000 /$ transatlantica.5835

ISSN : 1765-2766

Éditeur

Association française d'Etudes Américaines (AFEA)

Référence électronique

Jennifer A. Donnelly, "The New American Wing at The Metropolitan Museum of Art, New York »,

Transatlantica [En ligne], 1 | 2012, mis en ligne le 04 décembre 2012, consulté le 01 février 2023. URL : http://journals.openedition.org/transatlantica/5835; DOI : https://doi.org/10.4000/transatlantica. 5835

Ce document a été généré automatiquement le 1 février 2023.

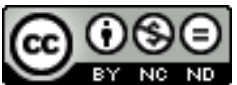

Creative Commons - Attribution - Pas d'Utilisation Commerciale - Pas de Modification 4.0 International - CC BY-NC-ND 4.0

https://creativecommons.org/licenses/by-nc-nd/4.0/ 


\title{
The New American Wing at The Metropolitan Museum of Art, New York
}

\author{
Jennifer A. Donnelly
}

1 Following renovations lasting over a decade, an expanded and fully reconfigured American Wing at the Metropolitan Museum of Art was unveiled in early 2012.

2 The Met's American collection is vast, spanning from colonial to contemporary and including painting, sculpture, photography, and a wide variety of decorative arts. The chronological sweep of the American Wing is approximately 1700 to $1910^{1}$, so visitors hoping to see the museum's key works by Jackson Pollock or Jasper Johns must walk across the building to the Modern and Contemporary section. Photography is also housed elsewhere, and the output of American Indians is included with the Arts of Africa, Oceania, and the Americas. Nonetheless, within its parameters the American Wing has a tremendous amount to show - over seventeen thousand objects fall under its aegis.

3 The project of renovation and expansion was carried out in three successive stages. The first, completed in 2007, involved what the museum terms the "classical arts of America", covering the period of 1810 to 1845 . The second phase recast the courtyard housing Beaux Arts sculptures and assorted architectural fragments. The department's Period Rooms were also refurbished at that time. The final phase saw the restaging of the paintings and sculpture on the second floor as well as the addition of a mezzanine level of decorative arts. In addition to benefitting from a ten percent increase in available exhibition space, the paintings are now all on one level, making for a more cohesive flow through the galleries (the previous arrangement had works by Thomas Eakins and John Singer Sargent squeezed awkwardly into a dim mezzanine).

4 The visit to the new American Wing begins in the sunlit Charles Engelhard court. The patron's name, scrupulously repeated throughout the Met's written material, is a reminder of how much American museums owe to private wealth and philanthropy. Capital's key role in the collections is also invoked by the 1820 façade of the Branch 
Bank of the United States that closes in one side of the courtyard. Another wall is formed by glass opening out onto Central Park with its abundance of colourful life, both plant and human. Overhead loom the mezzanine and balcony displays of art pottery, ceramics, silver and glass.

5 From ground level an elevator whisks museum-goers up to the second floor where a gilded eagle by William Rush, which once topped the pulpit at Saint John's Evangelical Lutheran Church in Philadelphia, heralds the entrance to the twenty-six ensuing galleries of paintings, sculptures, and decorative arts. In the distance several rooms away can be glimpsed a fragment of Emanuel Leutze's monumental Washington Crossing the Delaware (1851).

6 The ensuing galleries, unfolding in roughly chronological order, offer a rich visual encapsulation of significant moments in the political and cultural evolution of the United States from a far-flung hodgepodge of colonies into a nation emerging as a world power. Rooms of portraits, including one dedicated to John Singleton Copley, alternate with installations of elaborate wooden furniture and intricately wrought silver - the "utilitarian arts", as such objects were referred to in 1924 at the opening of the original American Wing. One is reminded that the American Wing employs more curators for decorative arts (five) than for paintings (a mere two).

7 The early years of the Republic and the first decades of the nineteenth century are represented by portraits, still lives, and folk art. At mid-century dawn the distinctly American subjects of Luminism and the Hudson River School. Washington Crossing the Delaware continues to be visible at several points in the path and eventually the canvas in its enormous entirety is reached, taking pride of place in the gallery "History, Landscape, and National Identity". Letuze's canvas, restored as well as placed in an elaborate frame painstakingly recreated from photos from the 1864 Sanitary Fair, is flanked by the transcendental landscapes of Frederic Church's Heart of the Andes (1859) and Albert Bierstadt's The Rocky Mountains, Lander's Peak (1863), also exhibited with it at the Sanitary Fair. The Civil War is represented notably by Winslow Homer. The last galleries move through accomplished schools and styles, alighting on the transatlantic moment and American Impressionism before ending with Gilded Age portraits, all velvet and silk, and the smoke and grit of the Ashcan School. The American Wing thus closes on a contrast between high society and street life.

8 The installation is clean and neutral, with gallery walls painted a pale cream and newly opened skylights letting in diffused natural light. The hanging, as well, is arguably clean and neutral. While several new publications accompanied the reopening, pedagogical interpretation in the galleries is reserved, with minimal wall text providing primarily cataloguing data. Critical discourses arising from postcolonial or gender studies are not in evidence. This approach seems curiously reserved at a moment of renewed scholarly scrutiny of museum narratives, whether in the Global Art Museum observatory in Karlsruhe or the EuNaMus research project of the European Commission. However, it must be remembered that the Metropolitan Museum is an institution that preserves objects and as such is a conservative institution. With its focus on the period from colonial era to roughly the start of the first World War, the American Wing tells a specific version of image making in the United States. Perhaps its lack of provocation could be read as itself provocative.

9 Those separated from New York by an ocean or other geographical boundaries can still enjoy excellent access to the American Wing via the department's multimedia portal. 
Most objects across the museum's collection could already be viewed online, with options to enlarge details, read interpretations, and peruse bibliographies. The American wing portal now also provides complete gallery views, so that the objects can be seen in the context of their installation. As an additional enticement for virtual visitors, the Met website has recently made its catalogues available online through the initiative MetPublications. Le musée imaginaire continue à s'agrandir.

Thanks goes to Emily C. Burns for her tour through the American Wing in June 2012.

\section{BIBLIOGRAPHIE}

Further reading

The American Wing at The Metropolitan Museum of Art : A Walking Guide, published by The Metropolitan Museum of Art in association with Scala Publishers Limited (2012).

WIERICH,Jochen Grand themes, Pennsylvania State University Press, 2012

BARRATT, Carrie Rebora, Lance MAYER and Gay MYERS, Suzanne SMEATON and Eli WILNER,Washington Crossing the Delaware : Restoring an American Masterpiece, published by The Metropolitan Museum of Art, Distributed by Yale University Press

\section{NOTES}

1. The official cutoff is artists born before 1876 , although there are some exceptions.

\section{INDEX}

Thèmes : Trans'Arts 